\title{
COMPARISON OF ESTIMATION METHODS OF SOIL STRENGTH IN FIVE SOILS ${ }^{(1)}$
}

\author{
Ayodele Ebenezer Ajayi ${ }^{(2)}$, Moacir de Souza Dias Junior ${ }^{(2)}$, Nilton Curi ${ }^{(2)}$, \\ Cezar Francisco Araujo Junior ${ }^{(4)}$, Olanike Olaiya Aladenola ${ }^{(3)}$, Thiago \\ Tadeu Teixeira Souza ${ }^{(2)} \&$ Alberto Vasconcellos Inda Junior ${ }^{(5)}$
}

\begin{abstract}
In agriculture, the soil strength is used to describe the susceptibility to deformation by pressure caused by agricultural machine. The purpose of this study was to compare different methods for estimating the inherent soil strength and to identify their suitability for the evaluation of load support capacity, compaction susceptibility and root growth. The physical, chemical, mineralogical and intrinsic strength properties of seven soil samples, collected from five sampling pits at different locations in Brazil, were measured. Four clay (CS) and three sandy clay loam (SCL) soils were used. The clay soils were collected on a farm in Santo Ângelo, RS (28 ${ }^{\circ} 16^{\prime} 16 " \mathrm{~S} ; 54^{\circ} 13^{\prime} 11$ "W $\left.290 \mathrm{~m}\right)$; A and B horizons at the Universidade Federal de Lavras, Lavras, MG (21 ${ }^{\circ} 13^{\prime} 47^{\prime}$ ' S; $44^{\circ} 58^{\prime}$ 6" W; $\left.918 \mathrm{~m}\right)$ and on the farm Sygenta, in Uberlandia, MG $\left(18^{\circ} 58^{\prime} 37\right.$ " $\mathrm{S} ; 48^{\circ} 12$ ' 05 " W $\left.866 \mathrm{~m}\right)$. The sandy clay loam soils were collected in Aracruz, ES (19 ${ }^{\circ} 47^{\prime} 10 " \mathrm{~S}$; $40{ }^{\circ} 16$ ' 29 " W $\left.81 \mathrm{~m}\right)$, and on the farm Xavier, Lavras, MG $\left(21^{\circ} 13^{\prime} 24\right.$ " $\mathrm{S}$; $\left.45^{\circ} 05,00 " \mathrm{~W} ; 844 \mathrm{~m}\right)$. Soil strength was estimated based on measurements of: (a) a pneumatic consolidometer, (b) manual pocket (non-rotating) penetrometer; and (c) automatic (rotating) penetrometer. The results of soil strength properties were similar by the three methods. The soil structure had a significant influence on soil strength. Results of measurements with both the manual pocket and the electric penetrometer were similar, emphasizing the influence of soil texture. The data showed that, to enhance the reliability of predictions of preconsolidation pressure by penetrometers, it is better to separate the soils into the different classes, rather than analyze them jointly. It can be concluded that the consolidometer method, although expensive, is the best when evaluations of load support capacity and compaction susceptibility of soil samples are desired.

Index terms: Penetration resistance; preconsolidation pressure; load support capacity.

\footnotetext{
(1) Departamento de Engenharia Agrícola. Universidade Federal de Tecnologia, PMB 704, Akure, Onto Sate, Nigéria.Recebido para publicação em julho de 2007 e aprovado em fevereiro de 2009.

(2) TWAS-CNPq Bolsista de Pós-Doutorado; Departamento de Ciência do Solo, Universidade Federal de Lavras - UFLA. Caixa Postal 3037, CEP 37200-000 Lavras (MG) Brasil. E-mails: ayo.ajayi@gmail.com; msouzadj@ufla.br; niltcuri@ufla.br; thiagottsouza@hotmail.com

(3) Programa Inter-Universidade em Engenharia de Recursos de Água (IUPWARE), Katholieke Universitiet, Leuven, Begium. E-mail: olanike4signs@yahoo.com

(4) Doutorando em Ciência do Solo, Departamento de Ciência do Solo, UFLA. E-mail: cfaj@bol.com.br

(5) Professor do Departamento de Solos, Faculdade de Agronomia, Universidade Federal do Rio Grande do Sul - UFRGS. Av. Bento Gonçalves 7712, CEP 91540-000 Porto Alegre (RS). E-mail: alberto.inda@ufrgs.br
} 


\title{
RESUMO: APLICAÇÃO DE DIFERENTES MÉTODOS PARA ESTIMAR A RESISTENNCIA DE CINCO SOLOS
}

\begin{abstract}
Na agricultura, a resistência do solo é usada para descrever a suscetibilidade a deformação através da pressão causada pelas máquinas agrícolas. Os objetivos deste estudo foram comparar diferentes métodos para estimar a resistência do solo e identificar suas potencialidades para avaliar a capacidade de suporte de carga, a suscetibilidade à compactação e o crescimento de raiz. Os atributos físicos, químicos, mineralógicos e de resistência de amostras de solo, coletadas em cinco trincheiras situadas em várias localidades no Brasil, foram medidos neste estudo. Quatro solos muito argilosos (CS) e três franco-argiloarenosos (SCL) foram usados. Os solos argilosos foram coletados em um Fazenda em Santo Angelo, RS (28 ${ }^{\circ} 16^{\prime} 16^{\prime}$ " $S$; $54^{\circ} 13^{\prime} 11$ " W; 290 m); e os horizontes A e B, na Universidade Federal de Lavras, Lavras, $M G\left(21^{\circ} 13^{\prime} 47^{\prime} S ; 4^{\circ} 58^{\prime} 6\right.$ " W; $918 \mathrm{~m}$ ), e na Fazenda da Syngenta, Uberlândia, $M G$ $\left(18^{\circ} 58^{\prime} 37^{\prime} \mathrm{S} ; 48^{\circ} 12^{\prime} 05\right.$ ” W; $\left.866 \mathrm{~m}\right)$. Os solos franco-argiloarenosos foram coletados em Aracruz, ES (19 ${ }^{\circ} 47^{\prime} 10^{\prime}$ ' S; $40^{\circ} 16^{\prime} 29$ ” W; $81 \mathrm{~m}$ ), e na Fazenda Xavier, Lavras, $M G$ $\left(21^{\circ} 13^{\prime} 24^{\prime} \mathrm{S} ; 4^{\circ} 05^{\prime} 00^{\prime} \mathrm{W} ; 844 \mathrm{~m}\right)$. A resistência dos solos foi obtida com um consolidômetro pneumático, penetrômetro de bolso manual (não giratório) e um penetrômetro automatizado (giratório). Os resultados da resistência do solo foram similares nos três métodos. A estrutura do solo influenciou significativamente sua resistência. Medições com o penetrômetro de bolso manual e o automatizado produziram resultados semelhantes, indicando influência da textura do solo. Os resultados mostraram que, para aumentar a confiabilidade na predição da pressão de preconsolidação usando penetrômetros, é melhor separar os solos em diferentes classes texturais do que analisá-las juntas. Apesar de o método do consolidômetro ser caro, conclui-se que este é o melhor método quando são desejadas avaliações da capacidade de suporte de carga e da suscetibilidade à compactação do solo.
\end{abstract}

Termos de indexação: pressão de preconsolidação, resistência à penetração, capacidade de suporte de carga.

\section{INTRODUCTION}

The strength of structured soils is a property of interest for applications in both agriculture and engineering. In the case of agricultural use, the inherent soil strength is useful to describe the susceptibility to deformation by pressure caused by farm machinery. The property is also important to specify the tilling machine to be used to change the soil structure at plowing to improve agricultural production (Ohu et al., 1986). In civil engineering, inherent soil strength determines the compaction level for an optimum stability of road bases (earth works), influences the capacity for supporting civil structures, while in water resources engineering, it determines the choice of the materials for earthdam and embankment constructions.

This property is also the focus of a number of studies aimed at curtailing the increasing degradation of agricultural soils, triggered by the demand for yield increase per unit area of agricultural land. It is believed that an adequate understanding of the soil inherent strength could contribute to improve soil management (Horn, 2004; Horn \& Lebert, 1994). In view of its importance, a number of variables has been developed for an adequate evaluation. The commonly used variables include: aggregate stability, preconsolidation pressure or precompression stress, shear strength and penetration resistance or pressure.
Preconsolidation pressure is an estimated value of the maximum pressure a soil had supported in the past (Dias Junior, 2003; Veiga et al., 2007; Dias Junior et al., 2007), and is a useful indicator of the intrinsic strength and load bearing capacity of a soil (Defossez \& Richard, 2002; Dias Junior et al., 2005; Rücknagel et al., 2007). It can be estimated from soil compression curves, determined in soil cores by a multistep device (Peng et al., 2004; Horn, 2004; Veiga et al., 2007), or from pedotransfer functions based on soil properties and soil-water interaction variables, e.g., texture classes, water retention, available water, bulk density, and aggregate stability (Imhoff et al., 2004; Rücknagel et al., 2007).

Shear strength measurements are based on the stress at soil failure, which is used for the calculation of the properties soil cohesion and angle of internal friction. Shear strength can be measured in direct shear, triaxial, and shear vane tests (Ohu et al., 1986; Horn \& Lebert, 1994). Unconfined soil strength can also be evaluated in penetration resistance measurements (Dauda \& Samari, 2002; Dias Junior et al., 2004; Lima et al., 2006). Soil penetrability is a measure of the ease with which an object can be pushed into the soil. The resistance to penetration of the soil to the penetrometer probe is related to the pressure required to form a spherical cavity of the size of the probe, which allows frictional resistance between the probe and surrounding soil. The soil-cone 
friction is then used to determine the resistance of the probe using theoretical stress relations from the compression zone around the probe (Dias Junior et al., 2004). Some studies showed that the estimation of the preconsolidation pressure based on the pedotransfer function of penetration resistance may be used to identify soil compaction (Mosadeghi et al., 2003; Dias Junior et al., 2004; Lima et al., 2006). However, a comparison among the different methods of estimating penetration resistance must be based on a number of factors that influence the measurement by an automatic penetrometer compared to the manual penetrometer (Motavalli et al., 2003; Whalley et al., 2005).

Rotating the automatic penetrometer probe was shown to enhance the representativeness of penetration resistance to root growth (Bengough et al., 1997). The pressure of a rotating penetrometer required to penetrate the soil is thought to be representative of the root pressure required to deform soil (Whalley et al., 2005). The effect of rotating the penetrometer decreases the axial soil-metal friction component that contributes to the force needed to push the penetrometer into the soil. Since the root - soil friction is low (Bengough \& McKenzie, 1997), the rotating penetrometer provides a better representation of root soil penetration than a fixed (non-rotating) penetrometer.
The purpose of this study was to compare three estimation methods for inherent soil strength and to identify their suitability to evaluate load support capacity, compaction susceptibility and root growth resistance.

\section{MATERIALS AND METHODS}

Four clay (CS) and three sandy clay loam (SCL) soils were used in this study (Table 1). All soil samples were Oxisols (Latosols, by the Brazilian classification system).

At each site, a $1 \times 2 \times 1 \mathrm{~m}$ pit was carefully dug for sampling. In Santo Ângelo, 25 samples were collected in the B-horizon (CS1). At the Federal University of Lavras, 25 samples each were collected from the A-horizon (CS2) and the B -horizon (CS3), while in Uberlândia 25 samples were collected in the B-horizon (CS4). In Aracruz, the B-horizon (SCL1) was sampled and on the Xavier Farm, 25 samples were collected from the surface (SCL2) and the Bhorizon (SCL3).

All these undisturbed soil cores were sampled in aluminum rings (diameter $6.5 \mathrm{~cm}$, height $2.5 \mathrm{~cm}$ ), using an Uhland sampler. The sampling device was driven into the soil using a falling weight. At each

Table 1. Sampling sites and soil descriptions

\begin{tabular}{|c|c|c|c|c|c|c|}
\hline $\begin{array}{l}\text { Label and } \\
\text { specific } \\
\text { location }\end{array}$ & $\begin{array}{c}\text { Geographical } \\
\text { coordinate } \\
\text { and altitude }\end{array}$ & $\begin{array}{c}\text { Climatic } \\
\text { description }\end{array}$ & $\begin{array}{l}\text { Brazilian soil } \\
\text { classification }^{(1)}\end{array}$ & Texture & $\begin{array}{c}\text { Parent } \\
\text { material }\end{array}$ & $\begin{array}{c}\text { Native } \\
\text { vegetation }\end{array}$ \\
\hline $\begin{array}{l}\text { Lavras - MG } \\
\text { Federal } \\
\text { University of } \\
\text { Lavras }\end{array}$ & $\begin{array}{l}21^{\circ} 13^{\prime} \quad 47 " \mathrm{~s} \\
44^{\circ} 58^{\prime} 6^{\prime \prime} \mathrm{W} \\
918 \mathrm{~m}\end{array}$ & $\begin{array}{l}\text { Gentle } \\
\text { temperate } \\
\text { with dry } \\
\text { winter and } \\
\text { rainy summer }\end{array}$ & $\begin{array}{l}\text { Dystroferric Red } \\
\text { Latosol }\end{array}$ & Clay & Gabbro & Forest \\
\hline $\begin{array}{l}\text { Lavras - MG } \\
\text { Xavier Farm }\end{array}$ & $\begin{array}{l}21^{\circ} 13^{\prime} 24^{\prime \prime} \mathrm{S} \\
45^{\circ} 05^{\prime} 00^{\prime \prime} \mathrm{W} \\
844 \mathrm{~m}\end{array}$ & $\begin{array}{l}\text { Gentle } \\
\text { temperate } \\
\text { with dry } \\
\text { winter and } \\
\text { rainy summer }\end{array}$ & $\begin{array}{l}\text { Dystrophic } \\
\text { Yellow Latosol }\end{array}$ & $\begin{array}{l}\text { Sandy } \\
\text { clay } \\
\text { loam }\end{array}$ & $\begin{array}{l}\text { Granitic } \\
\text { Gneiss }\end{array}$ & Forest \\
\hline $\begin{array}{l}\text { Uberlândia - } \\
\text { MG } \\
\text { Syngenta } \\
\text { Seed Farm }\end{array}$ & $\begin{array}{l}18^{\circ} 58^{\prime} 37 ", \mathrm{~S} ; \\
48^{\circ} 12^{\prime} 05^{\prime \prime} \mathrm{W} \\
866 \mathrm{~m}\end{array}$ & $\begin{array}{l}\text { Tropical } \\
\text { monsoonal } \\
\text { with dry } \\
\text { winter and } \\
\text { rainy summer }\end{array}$ & $\begin{array}{l}\text { Acric Red } \\
\text { Latosol }\end{array}$ & Clay & $\begin{array}{l}\text { Tertiary } \\
\text { d etritic } \\
\text { c over } \\
\text { sediments }\end{array}$ & Cerrado \\
\hline Aracruz - ES & $\begin{array}{l}19^{\circ} 47^{\prime} 10^{\prime \prime} \mathrm{S} ; \\
40^{\circ} 16^{\prime} 29^{\prime \prime} \mathrm{W} \\
81 \mathrm{~m}\end{array}$ & $\begin{array}{l}\text { Moisty } \\
\text { tropical with } \\
\text { dry winter and } \\
\text { rainy summer }\end{array}$ & $\begin{array}{l}\text { Dystrocohesive } \\
\text { Yellow Latosol }\end{array}$ & $\begin{array}{l}\text { Sandy } \\
\text { clay } \\
\text { loam }\end{array}$ & $\begin{array}{l}\text { Ba rreiras } \\
\text { g roup } \\
\text { sediments }\end{array}$ & Forest \\
\hline $\begin{array}{l}\text { Santo } \\
\text { Ângelo - RS }\end{array}$ & $\begin{array}{l}28^{\circ} 16^{\prime} 16^{\prime \prime} \mathrm{S} ; \\
54^{\circ} 13^{\prime} 11^{\prime \prime} \mathrm{W} \\
290 \mathrm{~m}\end{array}$ & $\begin{array}{l}\text { Moisty } \\
\text { tropical } \\
\text { without long } \\
\text { dry period }\end{array}$ & $\begin{array}{l}\text { Dystroferric } \\
\text { Red Latosol }\end{array}$ & Clay & Basalt & Forest \\
\hline
\end{tabular}

(1) According to Embrapa (2006). 
sampling point the ring filled with soil was removed from the Uhland sampler and wrapped in plastic and paraffin wax, for compressibility and other tests. In the laboratory, the soil cores were carefully trimmed to the size of their respective rings, whose inner diameter, height and weight had been pre-measured. Disturbed soil samples were obtained by scraping off spare soil from the top and bottom of the undisturbed soil cores were used, among other analyses to determine field soil moisture at sampling time. The residual disturbed soil samples were air-dried and passed through a $2 \mathrm{~mm}$ sieve and stored in plastic bags prior to other analyses. Basic soil physical and chemical analyses were performed according to standard Brazilian procedures as described by Embrapa (1997).

Twenty samples from each set were submitted to a multistep uni-axial compression test, equilibrated at different water contents using a floating ring consolidometer (S-450 Terraload Consolidation Device, Durham Geo Enterprises, USA) (Dias Junior \& Pierce, 1995; Assouline et al., 1997; Dias Junior et al., 2007). Each pressure was applied until $90 \%$ of the maximum deformation was reached and then the pressure was increased to the next level (Taylor, 1948). The applied pressure versus deformation data were used to construct the soil compression curves, from which the preconsolidation pressures $(\sigma p)$ were estimated and the load bearing capacity model of the samples constructed following the procedure of Dias Junior \& Pierce (1995).

Manual and automatic penetration resistance measurements were performed in two cores per sample set. Three manual (fixed) and three automatic (rotating) penetration resistance measurements were performed in each core. The samples were first saturated by capillarity using distilled water, and equilibrated step-wise to water suction 2 and $4 \mathrm{kPa}$ in the hanging column, and 6, 10, 33, 500 and $1500 \mathrm{kPa}$ on ceramic plates in pressure chambers.
At each pressure level, the soil weight and penetration resistance were measured. After the last set of measurements (at $1500 \mathrm{kPa}$ ), the soil samples were oven-dried at $105^{\circ} \mathrm{C}$ for $48 \mathrm{~h}$ to determine the moisture content (weight basis).

For the manual measurement (fixed/non-rotating probe) a Soiltest CL-700 pocket penetrometer (Soiltest 2205 Lee Street, Evaston, Illinois) was used, and a Soil Penetrometer model MA-933 (Marconi Equipamentos, Piracicaba, SP, Brazil) for the automatic measurement (rotating probe). The manual penetrometer has a cylindrical probe (diameter $3.15 \mathrm{~mm}$ ), which was carefully pushed into the soil to a reference mark, and the reading recorded in $\mathrm{kgf} \mathrm{cm}^{-2}$. The Marconi penetrometer probe has a cone tip (diameter $4 \mathrm{~mm}$, slant height $3 \mathrm{~mm}$, angle $45^{\circ}$ ). For measurements, the soil contained in the ring was placed on the penetrometer table and the electronically controlled probe was gradually driven into the soil at a revolution of $105 \mathrm{~mm} \mathrm{~min}^{-1}$ until about $22 \mathrm{~mm}$ of the probe was buried in the soil. The graph of the penetration resistance (kgf), versus time is displayed on a computer screen and the data stored in files for calculations.

Penetration resistance $\left(\mathrm{PR}_{\operatorname{man}}\right.$ for manual penetrometer and $\mathrm{PR}_{\text {aut }}$ for automatic penetrometer) was calculated by dividing the maximum force required to push the penetrometer into the core by the cross-sectional area of the cone base (Whaley et al., 2005). The data obtained were later analyzed and used to construct the water content vs. penetration pressure (unconfined strength) curve for each device used here.

\section{RESULTS AND DISCUSSION}

The soil water retention curves for the studied soils (Figure 1) shows that water retention in sample CS1

Table 2. Physical and chemical properties of the five soils studied

\begin{tabular}{|c|c|c|c|c|c|c|c|}
\hline Soil & CS1 & CS2 & CS3 & CS4 & SCL1 & SCL2 & SCL3 \\
\hline \multirow[t]{2}{*}{ Depth (m) } & $0.8-1.0$ & $0.2-0.4$ & $0.8-1.0$ & $0.8-1.0$ & $0.8-1.0$ & $0-0.1$ & $0.7-1.0$ \\
\hline & \multicolumn{7}{|c|}{ Physical properties } \\
\hline Munsell color (moist) & $10 \mathrm{R} 5 / 6$ & $10 \mathrm{R} \quad 4 / 6$ & $10 \mathrm{R} \quad 4 / 8$ & $2.5 \mathrm{YR} \quad 4 / 8$ & $10 \mathrm{R} \quad 4 / 6$ & 10YR $4 / 3$ & $7.5 \mathrm{YR} \quad 5 / 8$ \\
\hline Sand $\left(\mathrm{g} \mathrm{kg}^{-1}\right)$ & 90 & 140 & 160 & 300 & 660 & 500 & 460 \\
\hline Silt $\left(\mathrm{g} \mathrm{kg}^{-1}\right)$ & 170 & 160 & 190 & 80 & 60 & 210 & 220 \\
\hline Clay $\left(\mathrm{g} \mathrm{kg}^{-1}\right)$ & 740 & 700 & 650 & 620 & 280 & 290 & 320 \\
\hline Texture & $\mathrm{C}$ & $\mathrm{C}$ & $\mathrm{C}$ & $\mathrm{C}$ & SCL & SCL & $\mathrm{SCL}$ \\
\hline Particle density $\left(\mathrm{Mg} \mathrm{m}^{-3}\right)$ & 2.8 & 2.78 & 2.80 & 2.67 & 2.70 & 2.60 & 2.63 \\
\hline \multirow[t]{2}{*}{ Bulk density $\left(\mathrm{Mg} \mathrm{m}^{-3}\right)$} & 1.30 & 1.11 & 1.07 & 0.96 & 1.73 & 1.14 & 1.34 \\
\hline & \multicolumn{7}{|c|}{ Chemical property } \\
\hline Organic matter $\left(\mathrm{g} \mathrm{kg}^{-1}\right)$ & 16 & 25 & 19 & 12 & 3 & 29 & 13 \\
\hline
\end{tabular}

CS: clay soil; SCL: sandy-clay-loam. 
was higher at most water tensions, but lowest in SCL1 at all points, due to their very different clay contents. The figure 1 also shows the narrow range of water retention in many of the samples except in CS4, from 2 to $1500 \mathrm{kPa}$ suction, due to the granular structure. Moisture ranges were $0.08,0.13,0.16,0.29,0.08,0.14$, $0.10 \mathrm{~kg} \mathrm{~kg}^{-1}$, respectively, for $\mathrm{CS} 1, \mathrm{CS} 2, \mathrm{CS} 3, \mathrm{CS} 4$, SCL1, SCL2 and SCL3. The sandy clay loam soil (SCL1) was not able to hold much water due to the low clay percentage (Table 2) (Ferreira at al., 1999b; Reatto et al., 2007) and low specific surface area (West et al., 2004; Ajayi et al., 2009), whereas the structure of the clay soil CS1 retained the water tightly, even under increased tension, making extraction very difficult (Newman \& Brown, 1987; Ferreira et al., 1999a). The blocky structure of the SCL soils helps to explain the relatively higher water retention values. The water retention values of the soils provide the background for understanding the results of penetration resistance and load bearing capacity.

Although it appears that the moisture range in most of the soils was low, the water tension was in the range used in agricultural field operations (i.e. between field capacity $6 \mathrm{kPa}$ and permanent wilting point $1500 \mathrm{kPa}$ ) where most of the results of this study would find application. Hodgson (1997) classified the soil moisture range in: wet tension $<1 \mathrm{kPa}$; moist tension between 1 and $1500 \mathrm{kPa}$ and dry tension $>1500 \mathrm{kPa}$. Agricultural field operations should always be carried out at soil water tensions between field capacity and permanent wilting point to avoid permanent damage to the soil structure (cone index) determined with the manual and automatic penetrometers at different water tensions The measured values were best fitted with a two-parameter power equation, similar to previous studies (Dias Junior et al., 2004; Lima et al., 2006). The coefficient of determination varied from

Figures 2 and 3 show the penetration resitance (cone index) different water tension, with the manual and automated penetrometers. The measured values were best fitted with a two parameters power equation, similar to previous studies (Vaz et al., 2001; Dias Junior et al., 2004; Lima et al, 2006). The coefficient

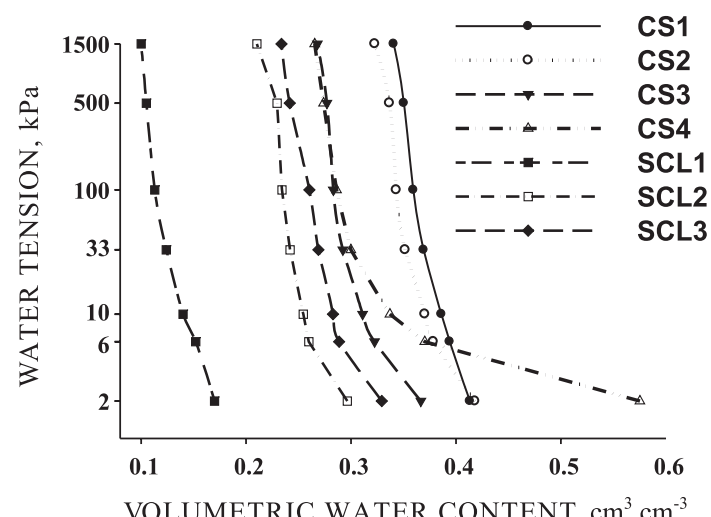

Figure 1. Soil water retention curves for soils studied.

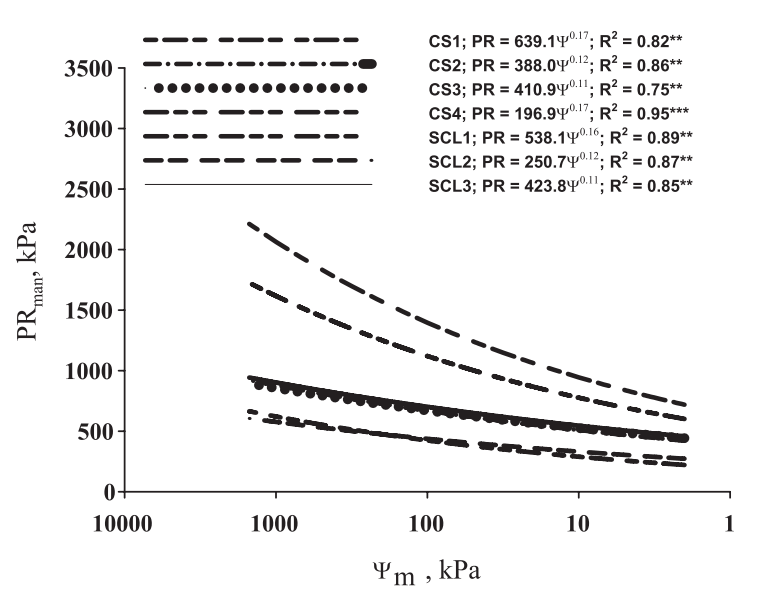

Figure 2. Soil penetration resistance (unconfined strength) measured with a pocket manual penetrometer, varying water tension.

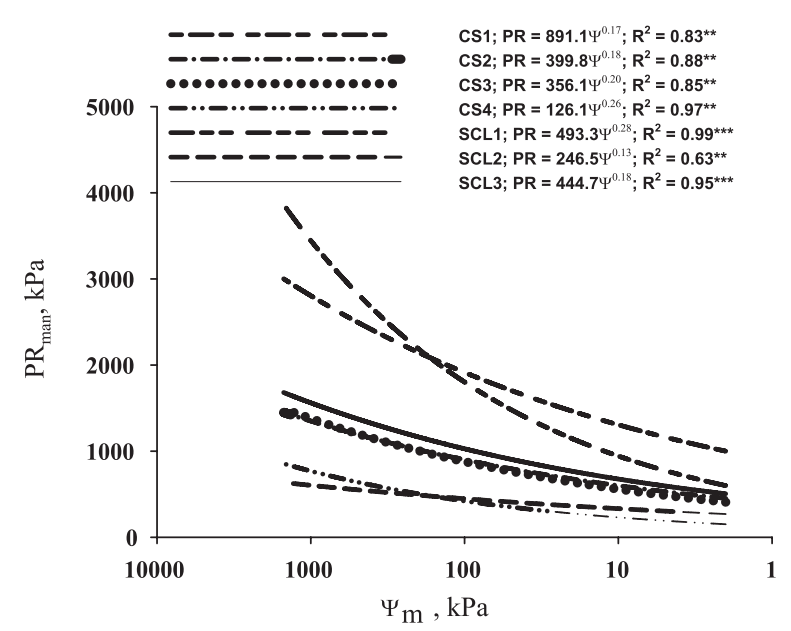

Figure 3. Soil penetration resistance (unconfined strength) in the soil samples measured with an automatic table penetrometer.

of determination varied from 0.75 to 0.95 for the fixed probes, while the range was from 0.63 to 0.99 for the rotating probes at different levels of significance as indicated in the equations.

For the manual measurement, the penetration resistance was highest in the clay soil (CS1) collected in Santo Ângelo, RS, followed by the sandy clay loam (SCL1) from Aracruz, ES. Penetration resistance was lower in the sandy clay loam from Lavras (SCL3) and the clay soil from Uberlandia (CS4). A similar pattern of penetration resistance was observed in the automatic measurement, but as the soil became drier, the sandy clay loam (SCL1) was more resistant than the CS1.

The results show the effect of mineralogy and soil moisture state on the mechanical soil properties, because soil mineralogy influences their structure. Fontes \& Weed, (1991), Resende et al. (2005) and Ajayi et al. (2009) showed that the soils from Aracruz, ES, 
and Santo Ângelo, RS, are very rich in kaolinite and have different proportions of Fe-oxides. The variation in Fe-oxide contents (CS1: $227 \mathrm{~g} \mathrm{~kg}^{-1} \mathrm{Fe}_{2} \mathrm{O}_{3}$; SCL1: $11 \mathrm{~g} \mathrm{~kg}^{-1} \mathrm{Fe}_{2} \mathrm{O}_{3}$ ) results in a differential resistance of the block structure, with decreasing resistance as moisture content increased in SCL1 and in CS1. The granular structure helps explain why the penetration resistance was low in CS4. Similarly, it was observed that penetration resistance increases as the soil dries out in all soils, in agreement with results published elsewhere (Dias Junior et al., 2004; Lima et al., 2006). An adequate understanding of soil penetration resistance at different moisture contants would therefore enhance early detection of stress on root growth, which may affect plant productivity. In dry soils, penetration resistance may be high and roots elongation inhibited, with a consequent detrimental effect on plant growth.

A comparison of the results showed that the values obtained by the automated measurements were higher in magnitude than those of manual measurements. The difference could be due to a number of factors, including a greater mean length in the automatic penetrometer compared to the manual penetrometer, the difference in the probe shape, and the difference in probe-state during measurement (i.e. rotating versus fixed) (Motavalli et al., 2003; Whalley et al., 2005). The automatic probe has a conical tip and penetrates deeper into the soil than the manual penetrometer, which has a flat tip and does not penetrate deeply, hampering a comparison of the results.

In view of the foregoing, the data of penetration resistance measured by the fixed penetrometer were related to those of the rotating penetrometers for all samples and all water tensions (Figure 4). The fixed penetrometer is very handy in the field, and results considered together with those of the more accurate rotating penetrometer would enhance the measurement precision for root growth monitoring in the field.

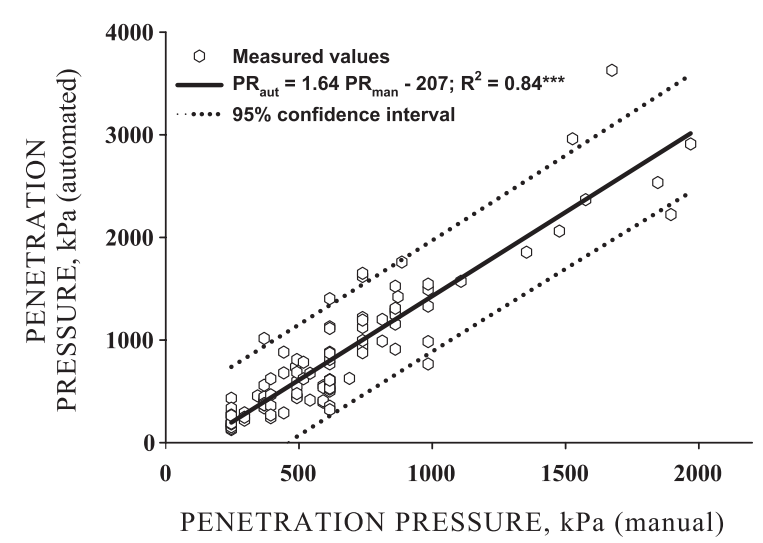

Figure 4. Relationship between penetration pressures measure manually and with automatic devices.
The result showed a linear relationship with a coefficient of determination $\left(\mathrm{R}^{2}\right)$ of $0.84^{* *}$. The $95 \%$ confidence interval showed that most data could be predicted by the derived relationship, except for some outliers in cases when the soil becomes too dry and the accuracy of any penetrometer is reduced. A fixed penetrometer could however be more suitable for detection and monitoring of soil compaction due to the apparent greater sensitivity of soil penetration resistance to changes in soil physical properties such as bulk density (Motavalli et al., 2003). Rotating the probe could also modify the soil resistance through compaction, and consequently the actual soil resistance may be masked.

The relationship between preconsolidation pressure values at different moisture contents (bearing capacity model), for a wider moisture range is presented in figure 5 .

For the ease of comparison of the shear strength of different soils, the preconsolidation pressure values were determined at different water contents equivalent to the water tensions used in this study in each soil (Figure 6). The extracted data were well fitted with a two-parameter power equation, with a coefficient of determination ranging from 0.68 to 0.94 , similar to the penetration pressure data. The values of preconsolidation pressure decrease as the water content increases, similarly as observed for penetration resistance (Figure 6). The pattern of preconsolidation pressure values in the moisture range used $(2 \mathrm{kPa}$ to1500 $\mathrm{kPa}$ ) was the same, though clearer, as observed in the penetrometer experiment. The results underscore the similarity in soil strength estimates of both penetration resistance and preconsolidation pressure (Dias Junior et al., 2004; Lima et al, 2006). The values of the estimated pressure were however different. The ratio preconsolidation pressure by penetration resistance $\left(\sigma_{\mathrm{p}}: \mathrm{PR}\right)$ for both manual and

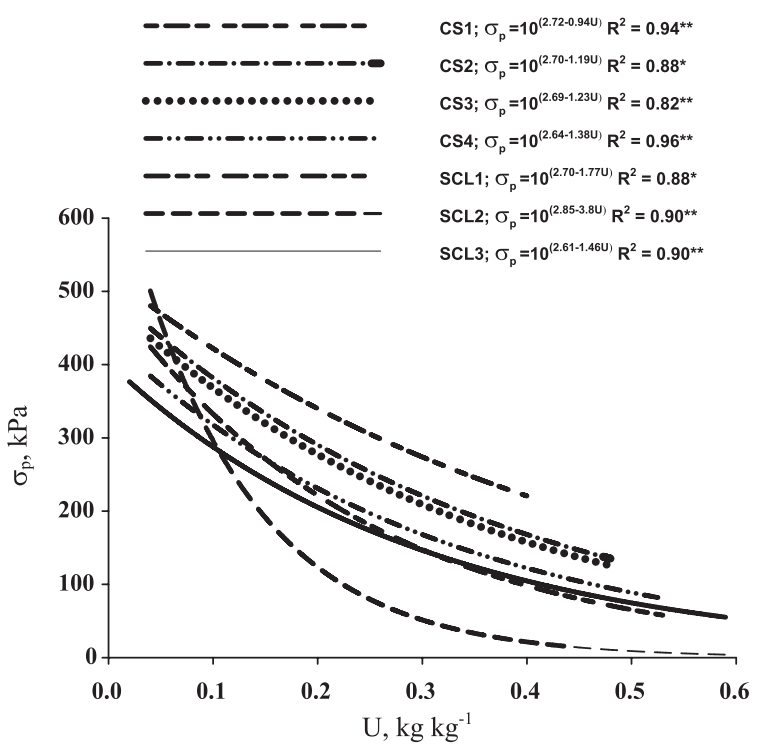

Figure 5. Bearing capacity models for the soil studied. 


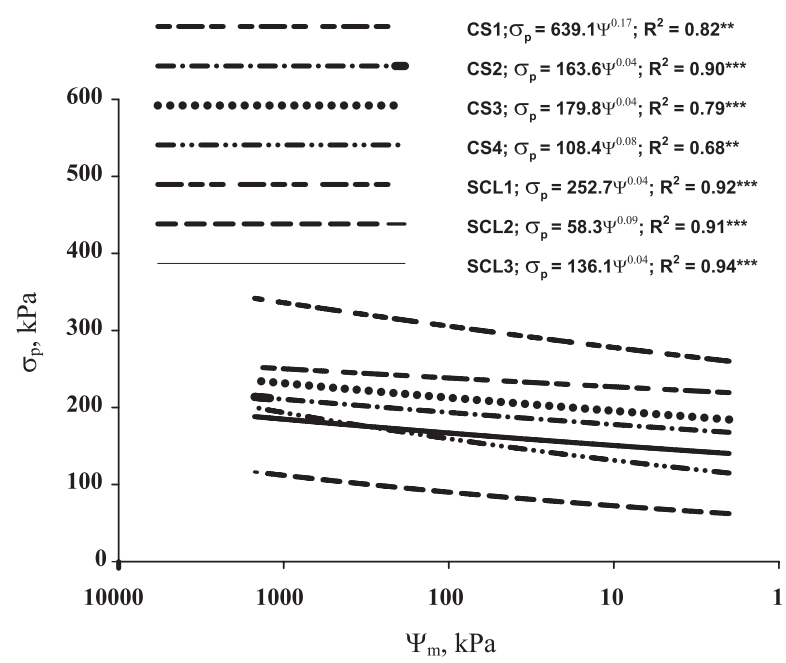

Figure 6. Preconsolidation pressure at varying water tensions.

automated measurements was $1: 6$ and $1: 11$, resepctively. In their study, Lima et al. (2006) reported a ratio $\sigma_{\mathrm{p}}: \mathrm{PR}$ of $1: 17$. This is possibly due to a wider range of soil moisture and different equipment used in that study.

A comparison of figures 2, 3 and 5 showed that the preconsolidation pressure values are more sensitive to changes in water retention whereas penetration resistance responds more to the soil physical properties, such as bulk density and texture properties. Compaction and other land degradation processes are basically an alteration of the soil structure (Or \& Ghezzehei, 2002; Mosadegghi et al., 2003; Jones et al., 2003; Spoor et al., 2003). They are known to generally reduce the water holding capacity of soils due to the loss of void spaces (Mosadegghi et al., 2000; Hamza \& Anderson, 2005), in association with changes in pore-size-distribution, depending on the tension considered. It would therefore be easier to detect changes in soil compression based on preconsolidation pressure rather than penetration resistance, which could be changed drastically by the presence of big pore in the soil or a high percentage of sand fraction.

To explore the advantage of similarity in response of the strength properties measured by the two penetrometer types and to estimate the preconsolidation pressure, the data of the two sets of penetrometer measurements were compared with the estimates of preconsolidation pressure based on the same moisture range as used here. In the first attempt (Figure 7) the data of all soil types under study were combined. They were fitted to a logarithm model, similar to results of Whalley et al. (2005), although the coefficients of determination for both data types (manual and automatic) were low (0.57 and 0.59, respectively). The data of the clayey and the sandy clay loam soils were therefore separated and the relations analyzed (Figures 8 and 9). The coefficient of determination was significantly improved,

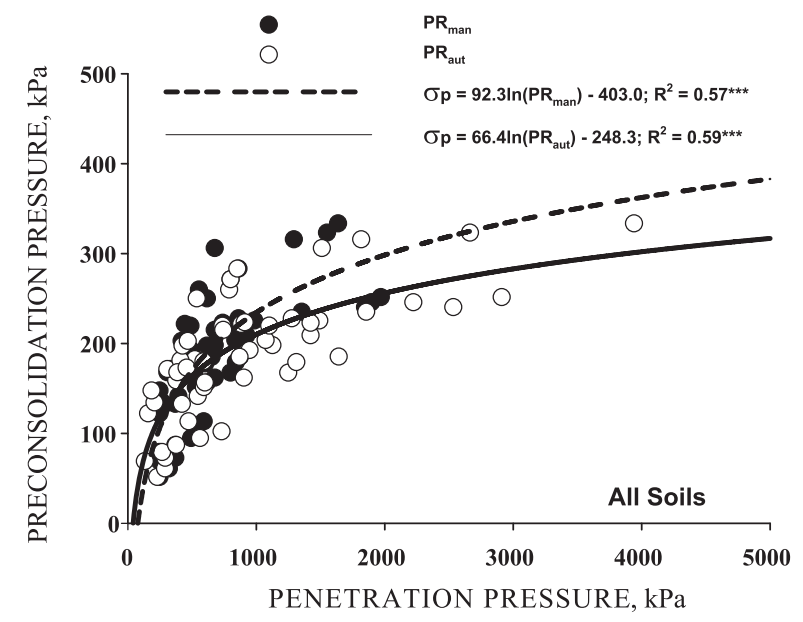

Figure 7. Relation between preconsolidation pressure and penetration resistance including clayey and sandy soils.

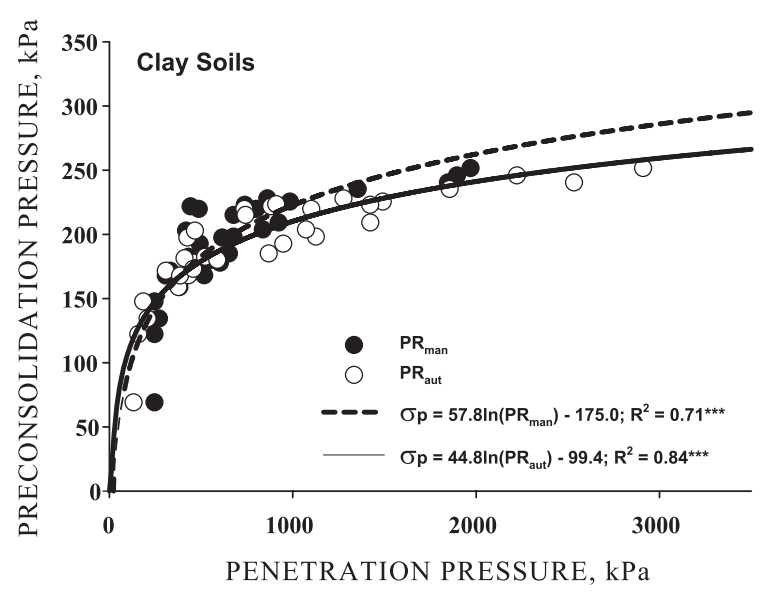

Figure 8. Relation between preconsolidation pressure and penetration resistance for clayey soils.

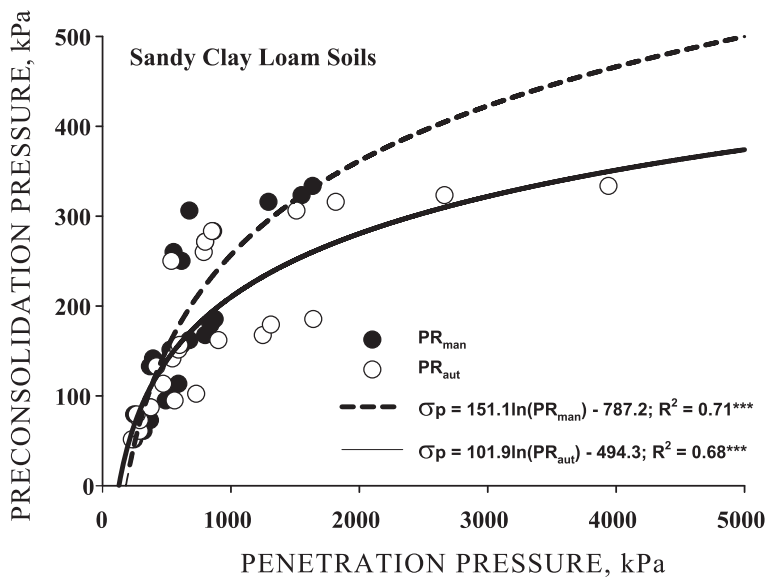

Figure 9. Relation between preconsolidation pressure and penetration resistance for sandy clay loam soils. 
particularly in the clay samples. The observation agreed with results of Kenan et al. (2004) and Ajayi et al. (2009), who showed that separating the clayey soils from sandy soils improved the predictability of compressive properties of soils from underlying data of soil physical properties.

\section{CONCLUSIONS}

Soil inherent strength can be estimated from both penetration resistance and preconsolidation pressure. To enhance the predictability of preconsolidation pressure from penetration resistance, it is better to separate the soils in different texture classes, rather than analyze them jointly

\section{ACKNOWLEDGEMENTS}

The first author acknowledges the support of the Third World Academy of Science (TWAS) and the Conselho Nacional de Desenvolvimento Científico e Tecnológico (CNPq), with a postdoctoral fellowship at the Universidade Federal de Lavras, during which this study was performed and the article written. We are grateful to the International Center for Theoretical Physics (ICTP) for initiating the College on Soil Physics which allowed the first author to meet the Brazilian advisor. We are also indebted to Delanne Robeiro and Dulce Claret Monteiro Moraes for their help with some laboratory analyses.

\section{LITERATURE CITED}

AJAYI, A.E.; DIAS JUNIOR, M.S.; CURI, N.; ARAUJO JUNIOR, C.F.; SOUZA, T.T.T. \& INDA JUNIOR, A.V. Strength properties and compaction susceptibility of Brazilian Latosols. Soil Till. Res., (STILL S -07- 194), 2009. (Submitted)

ASSOULINE, S.; TAVARES-FILHO, J. \& TESSIER, D. Effect of compaction on soil physical and hydraulic properties: Experimental results and modeling. Soil Sci. Soc. Am. J., 61:390-398, 1997.

BENGOUGH, A.G. \& MCKENZIE, B.M. Sloughing of root cap cells decreases the frictional resistance to maize (Zea mays L.) root growth. J. Exper. Bot., 48:885-893, 1997.

BengOUGH, A.G.; MUllins, C.E. \& WILsON, G. Estimating soil frictional resistance to metal probes and its relevance to the penetration of soil by roots. Eur. J. Soil Sci., 48:603-612, 1997.

DAUDA, A. \& SAMARI, A. Cowpea yield response to soil compaction under tractor traffic on a sandy loam soil in the semi-arid region of Northern Nigeria. Soil Till. Res., 68:17-22, 2002.
DEFOSSEZ, P. \& RICHARD, G. Models of soil compaction due to traffic and their evaluation. Soil Till. Res., 67:41-64, 2002.

DIAS JUNIOR, M.S. A soil mechanics approach study soil compaction In: ACHYUTHAN, H., ed. Soil and soil physics in continental environment. Chenna, Allied Publishers Private, 2003. p.179-199.

DIAS JUNIOR, M.S.; FONSECA, S.; ARAÚJO JUNIOR, C.F. \& SILVA, A.R. Soil compaction due to forest harvest operations. Pesq. Agropec. Bras., 42:257-264, 2007.

DIAS JUNIOR, M.S.; LEITE, P.F.; LASMAR JÚNIOR, E. \& ARAÚJO JUNIOR, C.F. Traffic effects on the soil preconsolidation pressure due to eucalyptus harvest operations. Sci. Agric., 62:248-255, 2005.

DIAS JUNIOR, M.S.; SILVA, A.R.; FONSECA, S. \& LEITE, F.P. Método alternativo de avaliação da pressão de preconsolidação por meio de um penetrômetro. R. Bras. Ci. Solo., 28:805-810, 2004.

DIAS JUNIOR, M.S. \& PIERCE, F.J. A simple procedure for estimating preconsolidation pressure from soil compression curves. Soil Technol., 8:139-151, 1995.

EMPRESA BRASILEIRA DE PESQUISA AGROPECUÁRIA EMBRAPA. Centro Nacional de Pesquisa de Solos. Manual de métodos de análise de solo. 2.ed. Rio de Janeiro, 1997. 212p.

FERREIRA, M.M.; FERNANDES, B. \& CURI, N. Mineralogia da fração argila e estrutura de Latossolos da região sudeste do Brasil. R. Bras. Ci. Solo., 23:507-514, 1999a.

FERREIRA, M.M.; FERNANDES, B. \& CURI, N. Influência da mineralogia da fração argila nas propriedades físicas de Latossolos da região sudeste do Brasil. R. Bras. Ci. Solo., 23:515-524, 1999b.

FONTES, M.P.F. \& WEEDS, S.B. Iron oxides in selected Brazilian Oxisols. Soil Sci. Soc. Am. J.,55:1143-1149, 1991.

HAMZA, M.A. \& ANDERSON, W.K. Soil compaction in cropping systems: A review of the nature, causes and possible solutions. Soil Till. Res., 82:121-145, 2005.

HODGSON, J.M., ed. Soil survey field handbook. Harpenden, 1997. 116p. (Soil Survey Technical Monograph, 5)

HORN, R. Compressibility of arable land. Catena, 11:53-71, 1988. (Supplement)

HORN, R. Time dependence of soil mechanical properties and pore functions for arable soils. Soil Sci. Soc. Am. J., 68:11311137, 2004.

HORN, R. \& LEBERT, M. Soil compactibility and compressibility. In: SOANE, B.D. \& van OUWERKERK, C., ed. Soil compaction in crop production. Amsterdam, Elsevier, 1994. p.45-69. (Development in Agricultural Engineering, v.11)

IMHOFF, S.; DA SILVA, A.P. \& FALLOW, D. Susceptibility to compaction, load support capacity, and soil compressibility of Hapludox. Soil Sci. Soc. Am. J., 68:17-24. 2004.

JONES, R.J.A.; SPOOR, G. \& THOMASSON, A.J. Vulnerability of subsoils in Europe to compaction: A preliminary analysis. Soil Till. Res., 73:131-143, 2003. 
KENAN, K.; ÖZGÖZ, E. \& AKBA,S.F. Assessment of spatial variability in penetration resistance as related to some soil physical properties of two fluvents in Turkey. Soil Till. Res., 76:1-11, 2004.

LIMA, C.L.R.; SILVA, A. P.; IMHOFF, S. \& LEÃO, T.P. Estimativa da capacidade de suporte de carga do solo a partir da avaliação da resistência à penetração. R. Bras. Ci. Solo., 30:217-223, 2006.

MOSADDEGHI, M.R.; HAJABBASI, M.A.; HEMMAT, A. \& AFYUNI, M. Soil compactibility as affected by soil moisture content and farmyard manure in central Iran. Soil Till. Res., 55:87-97, 2000.

MOSADDEGHI, M.R.; HEMMAT, A.; HAJABBASI, M.A. \& ALEXANDROU, A. Pre-compression stress and its relation with the physical and mechanical properties of a structurally unstable soil in central Iran. Soil Till. Res., 70:53-64, 2003.

MOTAVALLI, P.P.; ANDERSON, S.H.; PENGTHAMKEERATI, P. \& GANTZER, C.J. Use of soil cone penetrometers to detect the effects of compaction and organic amendments in claypan soils. Soil Till. Res., 74:103-114, 2003.

NEWMAN, A.C.D. \& BROWN, G. The chemical constitution of clays. In: NEWMAN, A.C.D., ed. Chemistry of clays and clay minerals. London, Mineralogical Society, 1987. p.1-128. (Mineralogical Society Monograph)

OHU, J.O.; RAGHAVAN, G.S.V.; MCKYES, E. \& MEHUYS, G. Shear strength prediction of compacted soil with varying added organic matter contents. Trans. Am. Soc. Agric. Eng., 29:351-355, 1986.

OR, D. \& GHEZZEHEI, T.A. Modeling post-tillage soil structural dynamics: A review. Soil Till. Res., 64:41-59, 2002 .
PENG, X.H.; HORN, R.; ZHANG, B. \& ZHAOA, Q.G. Mechanisms of soil vulnerability to compaction of homogenized and recompacted Ultisols. Soil Till. Res., $76: 125-137,2004$

REATTO, A.; BRUAND, A.; SILVA, E.M.; MARTINS, E.S. \& BROSSARD, M. Hydraulic properties of the diagnostic horizon of Latosol of a regional toposequence across the Brazilian Central Plateau. Geoderma, 139:51-59, 2007.

RESENDE, M.; CURI, N.; KER, C.J. \& REZENDE, S.R. Mineralogia de solos brasileiros - Interpretações e aplicações. Lavras, Universidade Federal de Lavras, 2005. $192 p$.

RÜCKNAGEL, J.; HOFMANN, B.; PAUL, R.; CHRISTEN, O. \& HÜLSBERGEN, K.J. Estimating precompression stress of structured soils on the basis of aggregate density and dry bulk density. Soil Till. Res., 92, 213-220, 2007.

SPOOR, G.; TIJINK, F.G.J. \& WEISSKOPF, P. Subsoil compaction: Risk, avoidance, identification and alleviation. Soil Till. Res., 73:175-182, 2003.

TAYLOR, D.W. Fundamentals of soil mechanics. New York, Wiley, 1948. 700p.

VEIGA, M.; HORN, R.; REINERT, D.J. \& REICHERT, M.J. Soil compressibility and penetrability of an Oxisol from Southern Brazil, as affected by long-term tillage systems. Soil Till. Res., 92:104-113, 2007.

WEST, S.L.; WHITE, G.N.; DENG, Y.; MCINNES, K.J.; JUO, A.S.R. \& DIXON, J.B. Kaolinite, halloysite and iron oxide influence on physical behavior of formulated soils. Soil Sci. Soc. Am. J., 68:1452-1460, 2004.

WHALLEY, W.R.; LEEDS-HARRISON, P.B.; CLARK, L.J. \& GOWIN, D.J.G. Use of effective stress to predict the penetrometer resistance of unsaturated agricultural soils. Soil Till. Res., 84:18-27, 2005. 
